\title{
Immunological Estimation of Luteinizing Hormone in the Urine
}

\author{
Jun MIYATA \\ Department of Obstetrics and Gynecology, Osaka University School of Medicine, Osaka, Japan \\ (Director : Professor Yoshio Ashitaka)
}

Measurement of luteinizing hormone (LH) in the urine has much significance in the diagnosis of menstrual disorders. Urinary LH assay has been previously carried out by troublesome, time-consuming bioassay. Recently, immunological method has become available for that purpose, since Wide and Gemzell (1961) reported LH-immunoassay using HCG antigen-antibody system which was based upon the cross-reaction between HCG and LH. It is the purpose of this report to demonstrate the cross-reaction between HCG and LH, to establish the immunological assay method of urinary LH and to investigate the relationship between immunological and biological activites of LH.

Anti-HGG sera were obtained from rabbits received 2 injections each of 1,000 IU of crude preparation of HCG (Primogonyl, HCG-P), freshly emulsified with complete Freund's adjuvant at two weeks interval. The injections were made in the footpads and i.d. After 3 weeks of rest, a series of booster injections with 1,000 IU of HCG-P without adjuvant were given i.p. nine times at every other day. Rabbits were bled 7 days after the last injection and the sera were kept. The antibody titers were in the range from 6,400 to 51,200 by tanned hemagglutination. Antiserum which had the highest antibody titer was used in this study.

This anti-HCG serum contained several antibodies which reacted not only with HCG but also with normal human serum (NHS) and child urine protein (CUP) by immunoelectrophoresis. In order to remove antibodies against proteins other than HCG, 1ml of anti-HCG serum was absorbed with $30 \mathrm{mg}$ of lyophilized NHS and $20 \mathrm{mg}$ of CUP, thus the absorbed anti-HCG serum showed one precipitin band only to HCG. This absorbed serum also showed one precipitin band to human menopausal gonadotropin (Pergonal, HMG-P) which contained LH and FSH by agar gel diffusion and immunoelectrophoresis, and this band completely coalosced to the band wnich appeared against HCG.

This absorbed anti-HCG serum was examined for neutralization of LH and FSH. An assay method based on the rate of increase in the weight of the ventral prostates of hypophysectomized male rats (Greep) was used for LH assay and Stcelman-Pohley's augmentation method was used for FSH assay. When $2 \mathrm{IU}$ or $4 \mathrm{IU}$ of $\mathrm{LH}$ and $2 \mathrm{IU}$ or $4 \mathrm{IU}$ of FSH were incubated with $0.002 \mathrm{ml}$ of absorbed anti-HCG serum at $37^{\circ} \mathrm{C}$ for 60 min., biological activity of LH was completely neutralized but the FSH activity was not. From the above immunological and biological results, it could be concluded that LH had a similar antigen to HCG and LH was completely neutralized with anti-HCG serum. 
The amount of LH in the urine is so small for immunoassay that concentration of urine using pervaporation, carbowax 6,000 and alcohol precipitation to $1: 20$ is necessary. The recovery of LH was almost complete. The components of medium to dissolve the standard HCG influenced the sensitivity of tanned hemagglutination inhibition reaction. The concentration from 1 to $1: 20$ of the child urine as the medium of HCG, showed 4 fold as sensitive as phosphate buffered saline, thus $1: 2$ concentrated child urine was used for the medium to dissolve the standard HCG or to dilute the test materials.

Ten women from 23 to 34 years old who had the normal menstrual cycle, were examined every day for BBT, and LH value in the first morning urine by immunoassay. Seven women who showed clearly biphasic BBT gave the peak of LH level, in the range from $80 \mathrm{IU}$ to $320 \mathrm{IU}$ HCG equivalent/L, from 15 to 13 days before next menstruation. These peaks coincided with the rise of BBT.

Three women among them were examined LH level in the urine by using immunological and biological methods simultaneously. The urine for each 48 hours during the cycle war collected, and $60 \mathrm{ml}$ of that was used for immunoassay and the rest was used for bioassay. The kaolin adsorption method by Bradbury-Matsushima was used to extract gonadotropin from the urine. The recovery of gonadotropin was found to be almost satisfactory by bioassay. In all three cases, the LH value by bioassay showed a peak around ovulation in accordance with the value by immunoassay, but FSH value was kept low level during whole cycle. Thus, the LH values by immunoassay were almost parallel with $\mathrm{LH}$ values by bioassay but not with FSH values.

From our immunological and biological simultaneous assay for LH, we could conclude that LH can be assayed immunologically for the clinical use, but there are still many problems to determine whether the antigenic substance measured by immunological method is the biologically active LH molecule or not.

In conclusion, 1. LH had a similar antigen to HCG. 2. LH level by immunoassay in the urine of women who had the normal menstrual cycle, showed a peak around ovulation. 3. FSH does not take part in the LH immunoassay. 4. LH level by immunoassay is almost parallel with that by bioassay. 5. LH immunoassay could be used for the clinical purpose.

(pp. 43〜56) 


\title{
ヒト下垂体性LHの免疫学的測定について
}

\author{
大阪大学医学部産科婦人科学教室 （主任 足高善雄教授） \\ 宮田順
}

(昭和 42 年 2 月 9 日受付)

\section{I 。緒言}

黄体化ホルモン (luteinizing hormone, 以下 LH と略す) の尿中排泄量の測定は, 産婦人科領域では, 間脳，下垂体，卵巣系の機能異常の有無を内分泌学的に知る方法として，その臨床的意義はきわめて大きい. しかし，LH の尿中排泄量は非常に少なく，しかも尿中より LH を純化精製するてとが困難であるため， その測定はてれまで煩雑で長時間を要するBioassay に依存していた，てのため Bioassay にとつてかわる， より簡単でしかも感度のよい LH 測定法の開発が求められてきた。

近年, 蛋白性ホルモンの Immunoassay の進歩は著しいものがある. なかでも LH とその生物学的作用 のきわめて類似する HCG (Human chorionic gonadotropin) の Immunoassay は，1960年，Wide およ び Gemzell ら ${ }^{1}$ が血球凝集阻止反応，Brody および Corlström $ら^{2}$ 少補体結合反応，McKean ${ }^{3}$ ) か沈降反応 による方法を発表して以来，飛躍的な研究成果がみられるようになつた，現在では，乙れらのうち比較的簡 単な血球凝集阻止反応（或は同じ原理に基ずく Latex 凝集阻止反応 ${ }^{4}$ ) 飞よる HCG 測定法が，乙れまで の Bioassay に比して応用性の高いてとが知られ，我が教室ではすでに routine test として，日常臨床に好 んで利用されている。 ${ }^{5) ~ 8) ~}$

LH-Immunoassay については, Wide および Gemzell ら ${ }^{9}$ (1961) が，LH と HGG の免疫学的交叉反 応に基ずき，HCG の Antigen-antibody system を用いて LH-Immunoassay が可能であると報告した。

LH-Immunoassay には，LH の Antigen-antibody system を用いるのが理想的ではあつても，精製純度 の高い LH を大量に得るてとは今日至難であると云つてよい，てれに反して HCG は比較的簡単に純度の 高いものを大量に抽出できるようになつたので，それ以来 HCG の Antigen-antibody system を用いて LH を免疫学的に測定しようとする試みがなされるようになつた。

しかし，未だ LH はもちろん HCG そのものも純粋には抽出されておらず，その抗原性についても不明 の点が多いので，てのような方法で LH か測定されても果して LH そのものがぞうか，あるいは免疫学的 測定值が直ちに生物学的活性を表わすととが可能であるのかどうかも明確ではない．てのような方法が臨床 応用されるためには，LH に対する特異性，生物学的活性との関係や測定法自体についても慎重な検討を加 えなければならない，そてで著者は，抗 HCG 家鬼血清および HCG 感作羊血球を用いた血球凝集阻止反 応による LH-Immunoassay そついて，てれらの問題点をまず基礎的に検討し，さらに臨床応用への可能性 そついて検討して若干の知見を得たので報告する.

\section{II. 基 礎 実 験}

HCG Antigen-antibody system を用いて LH を免疫学的に測定するためには，HCG と LH との間に 免疫学的に交叉反応の成立するてとが前提条件であり，ついで HCG に比し尿中排泄量が微量である LH の 免度学的測定法そのものにも多くの検討と吟味の必要が残されている。そてで基礎実験において，てれらの 問題について検討を行つた.

1. 実験材料ならびに方法

i）抗 HCG 血清の作製法

a) 抗原：部分精製 HCG 製剤である Primogonyl (Schering, 1 管 1000IU 含有，以下 HCG-P そ略 す）を用いた。 
b) 兔疫法 : HCG-P1000 IU $/ \mathrm{ml}$ を含有する生理的食塩水（以下生食水と略す）溶液を等量の Complete Freund's adjuvant (Difco) と water in oil の状態に混合し，雌性成熟家鬼（体重 2.5 3.0kg）の両足蹠 趾間および背部皮内に $0.1 \mathrm{ml}$ づつ 20 カ所，合計 $2 \mathrm{ml} ， 10001 \mathrm{U}$ を注射した。 2 避間後，同様の方法で一家鬼 当り 1000IU の HCG-P を注射し, さらに3 週間後より Booster injection として, 1000IU の HCG-P 生食水溶液を隔日に 9 回腹腔内に注射した。用いた HCG-P は，一家鬼につき総量 $110001 U$ である.

c) 採血：最終注射の 1 週間後心臟突刺により全採血し，血清を分離した後 $-20^{\circ} \mathrm{C}$ 亿凍結保存した. 実験 には $56^{\circ} \mathrm{C} ， 30$ 分 incubate して非㗢化を行つた後使用した。

\section{d) 吸収抗 HCG 血清の作製法}

抗 HCG 血清 $1 \mathrm{ml}$ 飞対して凍結乾燥した正常男子血清 (Normal human serum, 以下 NHS と略す) 30mg（蛋白量）および下垂体性 Gonadotropin（以下G と略す）を殆んど合まないととが知られている4才

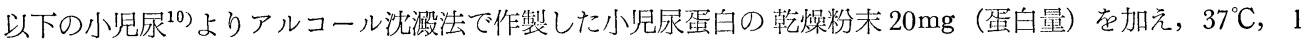
時間 incubate した後， $4{ }^{\circ} \mathrm{C}$ で一夜放置し，遠沈後その上清をとつた。

\section{ii）ゲル内沈降反応}

PH8.4の硼酸緩衝生食水 (Borate buffered saline, 以下 BBS と略す) に Special Agar Noble (Difco) を $0.85 \%$ 亿溶解して厚さ $1 \mathrm{~mm}$ の寒天板を作製した。抗原孔，抗体孔は共に直佳 $2.5 \mathrm{~mm}$, 抗原一抗体孔間 距離は $5 \mathrm{~mm}$ とした。抗原は BBS 溶液とし, 抗血清, 抗原溶液を毛細管を用いて各々 3 回該当する孔に充 壗した後, 恒湿箱中に一昼夜放置した。ついで生食水で一夜浸洗後さらに純水で 1 時間浸洗し, 乾燥させた 後, Amido black 10B にて染色して標本とした.

\section{iii）免疫電気泳動法}

$\mathrm{pH} 8.2 ，$ イオン強度 $0.05 \mu$ の Veronal 緩衝液に，0.85\% の Special Agar Noble (Difco) t溶解して 厚さ $1 \mathrm{~mm}$ の寒天板を作製し，直径 $2.5 \mathrm{~mm}$ の抗原孔を設け，抗原の BBS 溶液を 3 回充填した. $6 \mathrm{~V} / \mathrm{cm}, 45$ 分間通電により抗原を泳動させた後, 抗原孔端より $4 \mathrm{~mm}$ の所に幅 $1 \mathrm{~mm}$ の抗体瑇を設けて抗血清を 3 回充 媜した。一昼夜恒湿箱中に放置した後生食水で一夜浸洗後さらに純水で 1 時間浸洗し, 乾燥させた後 Amido black 10B で染色して標本とした。

iV) 血球疑集反応 (Hemagglutinaction reaction, HAR) および血球凝集阻止反応 (Hemagglutination inhibition reaction, HAIR)

\section{a) HCG 感作血球の作製法}

Wide および Gemzell らの方法1では成績の一定をみなていとがあつたので，ホルマリン化，タンニン酸 処理および HGG 感作時の条件に再検討を加え, 以下の方法によつて HCG 感作血球を作製した。

1）ホルマリン化

羊血球浮遊液 (Alsever's solution) を, pH7.2 の生食水で数回遠沈洗滌し，血球沈渣を $\mathrm{pH} 7.2$ の生食水 で $8 \%$ の浮遊液とする。

次いで血球浮遊液に等量の $\mathrm{pH} 7.2,3 \%$ ホルマリン生食水溶液を加え室温に20洔間放置し（時々振晹する）, 生食水で数回遠沈洗滌後，1/10000 の Merthiolate を含む生食水を加えて $10 \%$ 血球浮遊液として $4{ }^{\circ} \mathrm{C}$ で保 存した.

\section{ロ）タンニン酸処理}

10\%ホルマリン化血球浮遊液を $\mathrm{pH} 6.4$ の燐酸緩衝生食水 (Phosphate buffered saline, PBS) で 3 回遠 沈洗滌後, 血球沈渣を PBS で3.3\%浮遊液とする。乙れに $1 / 20000$ のタンニン酸を含むPBS 溶液を等量加 えて $37^{\circ} \mathrm{C}, 30$ 分間 incubate する。 その後 PBS で数回洗條し, 再び PBS にて $3.3 \%$ 血球浮遊液とする.

\section{八) HCG 感作}

$3.3 \%$ ホルマリン化，タンニン酸処理羊血球浮遊液に，HCG（純度 $5000 \mathrm{IU} / \mathrm{mg}$ ) を $100 \mathrm{IU} / \mathrm{ml}$ 含む PBS 溶液を等量加えて $56^{\circ} \mathrm{C}, 2$ 時間 incubate する. PBS で 2 回遠沈洗深し, 保存液 (PBS $45.5 \mathrm{ml}$, 非働化吸収 家鬼血清 $1 \mathrm{ml}$, 庶糖 $3.0 \mathrm{~g}, 1 \%$ Merthiolate 溶液 $0.5 \mathrm{ml}$ を混合したもの) で3.3\%の HCG 感作血球浮 
遊液とし，小試験管に分割注入して使用時迄－20 C に凍結保存した。また，3.3\%ホルマリン化，タンニン 酸処理血球浮遊液に等量のPBS を加えて同じ操作を行い，対照血球を作製した.

b) HAR

抗 HCG 家鬼血清を PBS で倍数稀釈し，その $0.45 \mathrm{ml}$ を 2 列の小試験管にとり，その 1 列には $3.3 \%$ HCG 感作血球浮遊液 $0.05 \mathrm{ml}$ を加え他の 1 列には対照血球を加えてよく振盪した後室温に静置した。 4 時 間後に管底より Stavitsky の方法に従つて凝集像を観察し, 何倍稀积迄凝集が生じたかを判定し, 凝集の認 められる最高の稀釈倍数をもつて抗体価とした。

c) HAIR

Fig. 1 のように, 横二列の小試験管に稀釈した抗 HCG 血清 $0.1 \mathrm{ml}$ 入れ, 倍数稀釉した検体(1)を縦二列

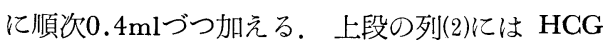
感作血球浮遊液を, 下段の列 (3) 亿は対照血球浮 遊液を各々 $0.05 \mathrm{ml}$ づつ加えてよく振盪し, 室温 放置 4 時間後管底を観察して, 検体の何倍稀釈迄 凝集阻止が認められるかを Stavitsky の方法 ${ }^{11)}$ で 判定した(4)。乙の時, 対照血球群(3)には非特異的 凝集像のないととを確認した。 また，同時に同じ 操作を, 既知単位の標準 HCG 溶液 (5000IU/mg の HGG Standard HCG としてもちいた. 以下 St. HCG と略す) について行ない, 凝集阻 止に必要な最低の $H C G$ 濃度 (IU/L) を求めて 免疫学的反応系の凝集阻止感度とし, ての值倹 体の凝集阻止を生じた最高稀釈倍数を乗じて, 検 体 $1 \mathrm{~L}$ 中の LH を, HCG 相当量 (HCG equivalent) として表わした。

また，HAIR を行う時は毎回必ず Fig. 1 のよ うに稀釈液対照, 抗血清対照をとつて, 免度学的 反応系が正しく作㗢していることを確認した。な お，検体の倍数稀釈には，PBS，G を含まないと Fig. 1. HAIR

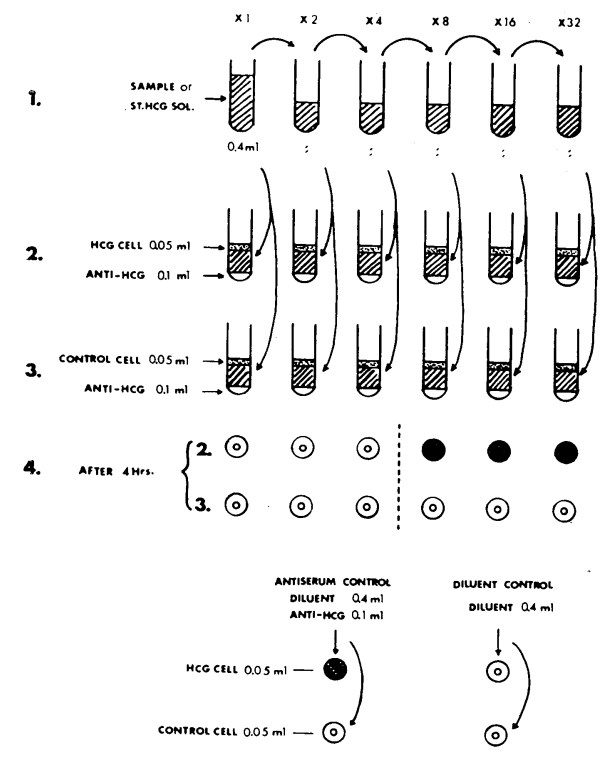
されている 4 才以下の小児尿蛋白液（後にのべる被検尿の濃縮法に準じて作製した）などを使用した。

v) 生物学的活性の中知実験

抗 HCG 血清に下垂体性Gとして，FSH および LH を含む HMG 製剂である Pergonal-500TM (Instituto Farmacologico Serono, HMG-P) を加えて $37^{\circ} \mathrm{C}, 1$ 時間 incubate し, $4{ }^{\circ} \mathrm{C}$ で一夜放置した後 LH-, FSH-Bioassay を行ない, 各々の生物学的活性に対する抗 HCG 血清の中和作用を検討した。

vi) LH-, FSH-Bioassay

a) LH-Bioassay

Greep $^{12)}$-三宅変法 ${ }^{13)}$ 亿準じて，生後21日目，体重 30 40g の Sprague-Dawley 系雄ラットを用意し，生 後22日目に，小山一田中変法 ${ }^{14} に よ り$ 経耳道的に下垂体を適出し，生後23日目より検体を 1 日 1 回 4 日間連 続背部皮下に注射した。最終注射の翌日屠殺して腹側前立腺重量を科量し，生食水を同様に投与した対照ラ ットの同重量に対する增加比（Rate）を求めて LH 活性の指標とした。また屠殺時開頭を行つて下垂体摘 出の完否を検べ, 摘出不完全なものは除外した.

b) FSH-Bioassay

Steelman-Pohley ${ }^{15}$-三宅変法 ${ }^{13}$ 亿準じて, 生後21日目，体重30４0g の Sprague-Dawley 系雌ラットを用 意し，生後23日目より，40IU の HCG を添加した検体を 1 日 1 回 4 日間連続背部皮下に注射した。最終注 
射の翌日屠殺して両側卵巣重量を科量し，体重 $100 \mathrm{~g}$ 当りの重量 (mg\%) に換算し，同様に HCG 40IU の み注射した対照群ラットの同重量に対する増加比を求めて FSH 活性の指標とした。

\section{2. 実験成績}

i) 抗 HCG 血清の純化

抗 HCG 血清の作製に抗原として用いた HCG-P は部分精製品であるため，HCG 以外の蛋白が混在し ているものと思われる。したがつて，そのような夾雑蛋白に対する抗体も同時に産生されている可能性があ る.そこで，HCG に対する抗体のみ有する抗血清の作製を試みた。

\section{a) 抗体価測定}

HCG-P で免疫した 4 羽の家兔より得た抗 HCG 血清につき, 血球凝集反応により抗体価を測定すると,

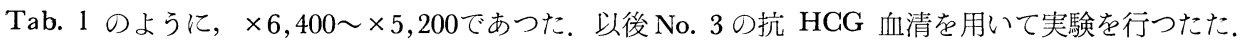

\section{b) 免疫電気泳動法}

抗 HCG 血清中に含まれる夾雑蛋白に対する抗 体を検出するため，抗原として，免疫に用いた HGG-P の 5000IU $/ \mathrm{ml}$ 溶液, HGG を含まない $\mathrm{NHS} の 50 \mathrm{mg} / \mathrm{ml}$ (蛋白量) 溶液および $\mathrm{G}$ を含 まない CUP の $40 \mathrm{mg} / \mathrm{ml}$ (蛋白量) 溶液と抗 HCG 血清を用いて免疫電気泳動を行うと, Fig. 2 のように，抗 HCG 血清と，HCG-P の間に

Table 1. Antibody titer of antisera

\begin{tabular}{c|c}
\hline No. of rabbits & Antibody titer \\
\hline No. 1 & $\times 12800$ \\
No. 2 & $\times 25600$ \\
No. 3 & $\times 51200$ \\
No. 4 & $\times 6400$ \\
\hline
\end{tabular}
は, 5〜6本の沈降線がみられ, 同時に NHS, CUP との間にも数本の沈降線がみられた，このことより抗原として用いた HCG-P 中には，HCG 以外の 血清蛋白，尿蛋白が混在し，抗血清中にはこれら夾雑蛋白に対する抗体も同時に産生されていることが明ら かになつた.

このような夾雑蛋白に対する抗体を除くため，抗 HCG 血清を NHS および CUP にて吸収すると， Fig. 3 のようにもはや NHS, CUP とは反応しないで HCG-P とのみ一本の沈降線を形成する吸収抗HCG 血清が得られた，以後この吸収抗 HCG 血清を用いて実験を行つた。

ii）抗 HCG 血清に対する LH の抗原性について

吸収抗 HCH 血清に対する LH の抗原性を検討するため，LH および FSH を含む HMG-P について，

Fig. 2. Immunoelectrophoresis (Before absorption)

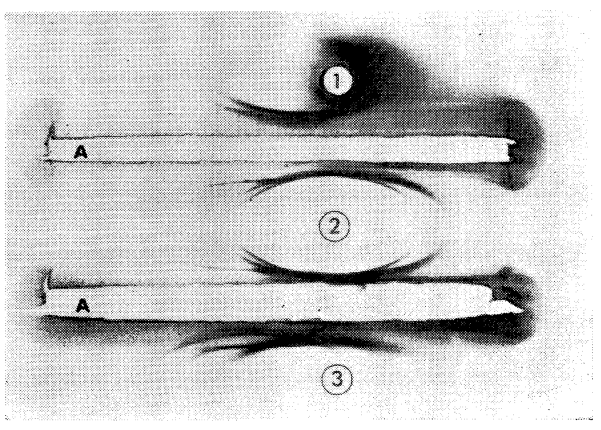

1 : Normal human serum

2 : HCG-P

3 : Child urine proteine

A : Unabsorbed anti-HCG
Fig. 3. Immunoelectrophresis (After absorption)

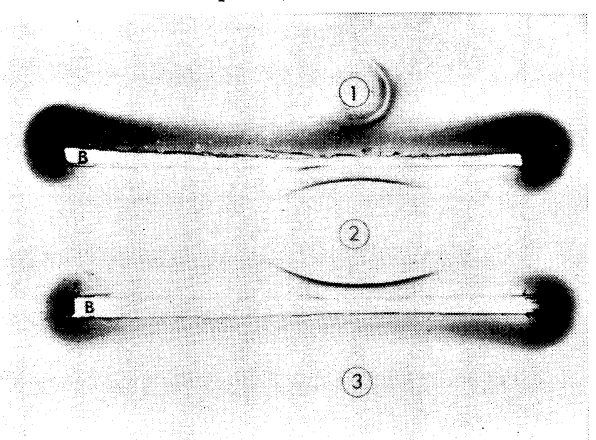

1 : Normal human serum

2 : HCG-P

3 : Child urine proteine

B : Absorbed anti-HCG 
血球凝集阻止反応，ゲル内沈降反応，免疫電気泳動法および生物活性の中和実験を行つた. HMG-P は，1 管10mg中に 75IU の LH および FSH を含む乾燥粉末製剂である.

a) HAIR

HMG-P そついて, 吸収抗 HCG 血清を用いて HAIR を行うと，明らかな凝集阻止がみられ，HMG-P, $1 \mathrm{mg}$ は約 2IU の HCG に相当する抗原性を示すてとを知つた。

b) ゲル内沈降反応

抗原孔に各々 HMG-P 500IU HCG eq/ml, HCG-P 500IU $/ \mathrm{ml}$ および St. HCG 500IU/ml をいれ，中 央の抗体孔に吸収抗 HCG 血清を入れると, Fig. 4 のように, HMG-P は, 吸収抗 HCG 血清に対して単 一な沈降線を形成し，しかも HCG-P, St. HCG の沈降線と全く一つに融合した。乙の場合 spur formatoin はみられなかつた。

Fig. 4. Agar gel diffusion

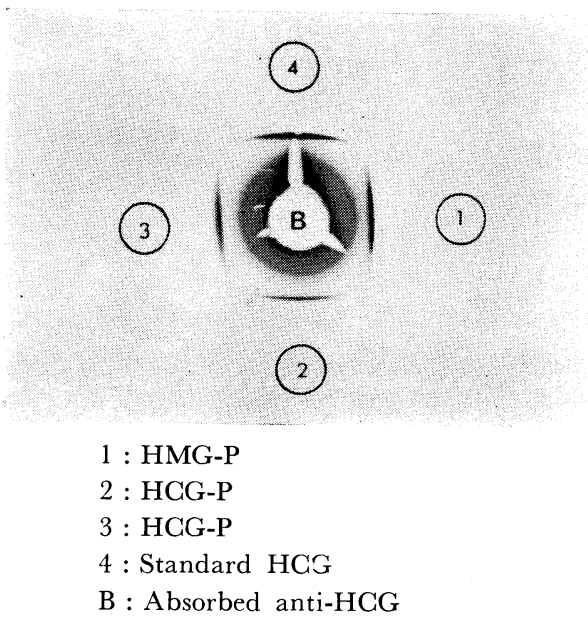

Fig. 5. Immunoelectrophoresis

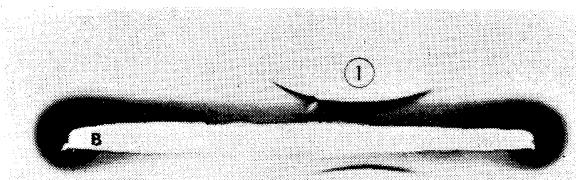

(2)

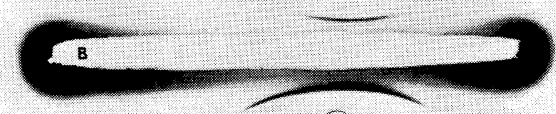

(3)
1 : HCG-P
2 : HMG-P
3 : Standard HCG
B : Absorbed anti-HCG

\section{c) 免疫電気泳動法}

抗原として, HMG-P 5000IU HCG eq/ml, HGG$\mathrm{P}$ および St. HGG 各々 $2000 \mathrm{IU} / \mathrm{ml}$ を電気泳動させ た後, 吸収抗 HCG 血清と反応させると, Fig. 5 の ように, HMG-P の沈降線は HCG-P 或は St. HCG と同じ位置に出現し，しかも抗血清瑇を途中で切ると， Fig. 6 のように HMG-P の沈降線は HCG-P 或は St. HCG の沈降線とそれぞれ一本に融合した.

\section{d) 生物学的活性中和実験}

2IU および 4IU の LH, FSH そ相当する HMGP に対して抗 HCG 血清 $0.002 \mathrm{ml}$ ⿸加えて incubate した後, LH-, FSH-Bioassay を行うと, Fig. 7 に示 すように，抗 HCG 血清により, HMG-P の FSH 活性は有意の減少を示さないが，LH 活性は明らかに 中和されて著しく減弱した。なお，FSH-Bioassay で

Fig. 6. Immunoelectrophoresis

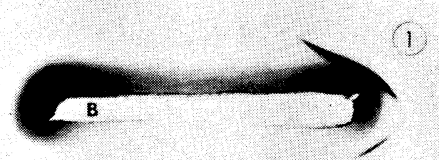

(2)

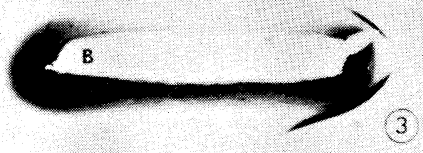

1 ; HGG-P

2 : HMG-P

3 : Standard HCG

B : Absorbed anti-HCG

は，負荷した HCG が，抗 HCG 血清により中和されて augmentation effect が減少する可能性もあるの

で HCG 40IU に，実験群と同量の抗 HCG 血清を加えたものを注射しててれを対照とした。

iii） HAIR におよぼす尿成分の濃度変化の影響 
Fig. 7. Neutralization of biological activities of HMG-P by anti-HCG
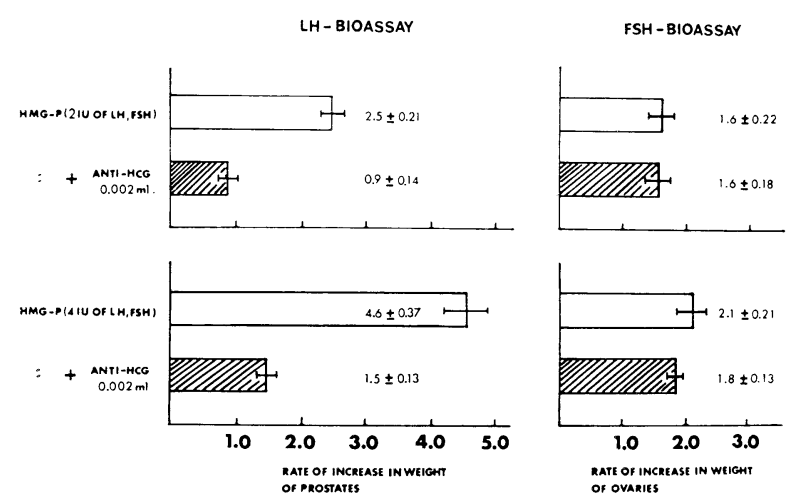

止反応を行い，尿成分の濃度変化が㠜集阻止反応 におよぼす影響を観察した。

Tab. 2 のように， 1 倍〜20倍の範囲内の尿成 分の濃度変化では，凝集阻止感度は変化しないが， PBS を用いた場合と比較すると， $1 / 4 の$ HCG 濃 度で凝集阻止が認められた。したがつて，濃縮さ れた被検尿を用いて Immunoassay を行うとき， 検体，標準 HCG の稀釈に PBS を用いると実際 より4倍高い值が得られることになる。乙の場合, 1 ２0倍に濃縮された小児尿を稀釈液として用い ると，正しい值が得られることになる。
尿中 LH の生理的排泄量はきわ めてわずかであるため，尿中 LH のImmunoassay には，被検尿を 予め濃縮しててれを検体とし，その 倍数稀釈系列について凝集阻止反応 を行う要がある。この時倍数稀釈 のため尿成分の濃度は高濃度から低 濃度に大きく変化する，尿成分の濃 度変化が㠜集阻止反応に非特異的な 影響を与えることはすでに教室より 報告している ${ }^{16)}$ ．乙の点を濃縮尿に つて 検討するため, 既知単位の HCG を含む PBS および種々な濃 度の小児尿蛋白液について，凝集阻
Table 2. Influence of diluents on the sensitivity of HAIR

\begin{tabular}{|c|c|c|c|c|}
\hline $\begin{array}{l}\text { HCG IU } / \mathrm{ml} \\
\text { Diluents }\end{array}$ & 1.6 & 0.8 & 0.4 & 0.2 \\
\hline PBS & 0 & & & \\
\hline $\begin{array}{l}\text { X20 concentrated } \\
\text { child urine }\end{array}$ & & & 0 & \\
\hline$\times 5 \quad$ " & & & 0 & \\
\hline$\times 2$ & & & 0 & \\
\hline$\times 1 \quad$ " & & & 0 & \\
\hline
\end{tabular}

\section{III. 臨 床 実 験}

月経周期の尿中 LH の排泄量は，乙れまでの Bioassay では，排卵期に一致してピークを示すことが知ら れている ${ }^{17) ~ 20)}$ ，基礎実験において検討した LH-Immunoassay でも同様に排卵期尿に LH 排泄のピークを 訨明し得るかどうか，又とのような測定值が果して LH の Bioassay と平行するかどうかを検討した.

\section{1. 実験対象亡実験方法}

i）実験対象 問診により正常月経周期を有する23才から34才の婦人を対象とした。

ii）実験方法 実験対象とした婦人につき，月経周期を通じて基礎体温（BBT） を記録させるとともに連 日早朝尿を採取させて，その LH-Immunoassay を試みた。 又，月経周期の各時期に48時間尿を数回採取し て，その一部を用いて LH-Immunoassay を, 残りの尿について LH-, FSH-Bioassay を行ない Immunoassay と Bioassay の相関について検討した。

\section{a) LH-Immunoassay}

\section{1）検体の作製}

被検尿 $60 \mathrm{ml}$ を滤過し，Visking tube につめ，Polyaethylen glycolum 6000 をふりかけて一夜 $4{ }^{\circ} \mathrm{C}$ に放 置して濃縮する. 内容を他の容器にうつして Visking tube 内を PBS で数回洗涤して洗液を濃縮尿に加え て最初の $1 / 10$ 容，すなわち $6 \mathrm{ml}$ とする。水醋酸で被検尿を $\mathrm{pH} 4.5$ ～ 5.0 とし，4 倍量の99\%泠エタノールを 加えて $4{ }^{\circ} \mathrm{C}$ 数時間放置した後遠沈し，沈澱をエタノール，エーテルで各々 1 回洗滌後乾燥させ，PBS で最 初の $1 / 20$ 容, $3 \mathrm{ml}$ に溶解して，20倍濃縮被検尿とした。 
なお，既知量の HMG-P の小児尿溶液について同じ操作を行つて，次にのべる LH-Immunoassay によ

り LH の回収率をみると, 略完全に回収されることを知つた。

\section{口）尿中 LH の Immunoassay 実施法}

1000倍稀釈吸収抗 HCG 血清を用いて，20倍濃縮被検尿につき，基礎実験 1-iv-c でのべた方法により LH を測定した，なお，検体の倍数稀釈，標準 HCG 溶液の作製，倍数稀釈には，基礎実験 2-iii で検討 した結果にもとづいて，検体と同様の方法で作製した 2 倍濃縮小児尿蛋白液を稀釈液として用いた。 ての時 の免疫学的反応系の凝集阻止感度は $200 \mathrm{IU} / \mathrm{L}$ であつた.

b) 尿中 LH-, FSH-Bioassay

\section{1) 尿中 $G$ 抽出法}

48時間尿より, Bradbury- ${ }^{21)}$ 松島変法 ${ }^{22}$ そしたがつてカオリン吸着, $\mathrm{NH}_{4} \mathrm{OH}$ 抽出，エタノール沈澱によ り, Gの粗抽出を行つた。 なお既知 量の HMG-P の小児尿溶液につい て同じ操作を行つて，次にのべる LH-, FSH-Bioassay を行ない回収 率をしらべると, 略完全であつた.

口) 尿中 LH の Bioassay

さきにのべた Greep ${ }^{12)}$-三宅変法 ${ }^{13)}$ に準じて行つた. 被検ラットは一群 4 匹とし，1 匹につき総量 8 時間尿 相当の $\mathrm{G}$ 抽出物生食水溶液を注射し た.

\section{八）尿中 FSH の Bioassay}

さきにのべた Steelman-Pohley ${ }^{15}$ 三宅変法 ${ }^{13)}$ 亿準じて行つた. 被検う ットは 1 群 2 匹とし，1 匹につき総 量 8 時間尿相当の $\mathrm{G}$ 抽出物生食水溶 液に HCG 20IU を負荷して注射し た.

\section{2. 実験成績}

i) 正常月経周期婦人の早朝尿中 LH-Immunoassay

LH-Immunoassay を試みた症例 のうち， BBT が明らかに二相性変 化を示した 7 例の正常月経周期婦人 の早朝尿中 LH の排泄パターンを Fig. 8〜14 に示した.

症例 Y-1 (23才, 未婚, Fig. 8) で は, 月経周期の第18日（次回月経前 13日目）に 320IU HCGeq./L の ピークを示した。 同一個人につい て，一周期をおいてもう一度測定を 行なうと (Y-2, Fig. 9), 月経周期の 第15，16日 (次回月経前14，13日目)

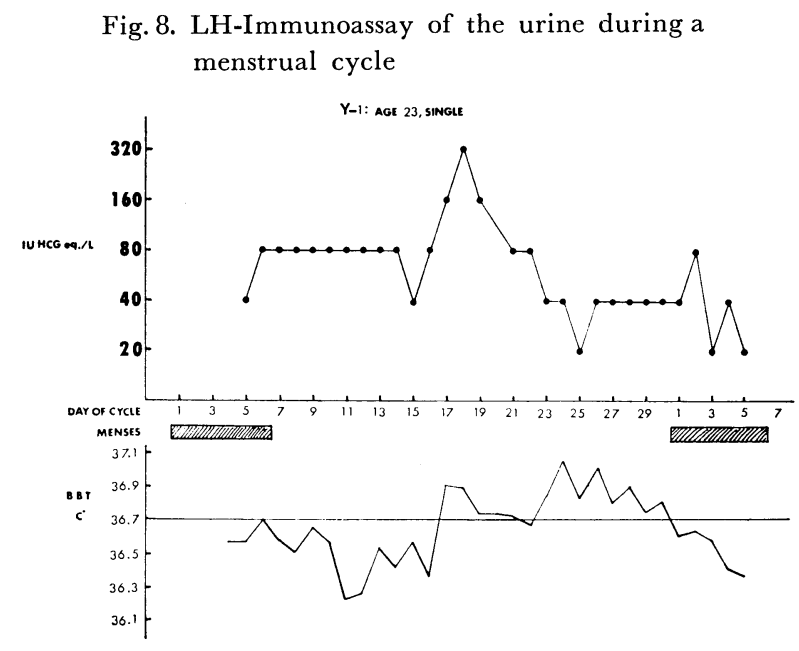

Fig. 9. LH-Immunoassay of the urine during a menstrual cycle

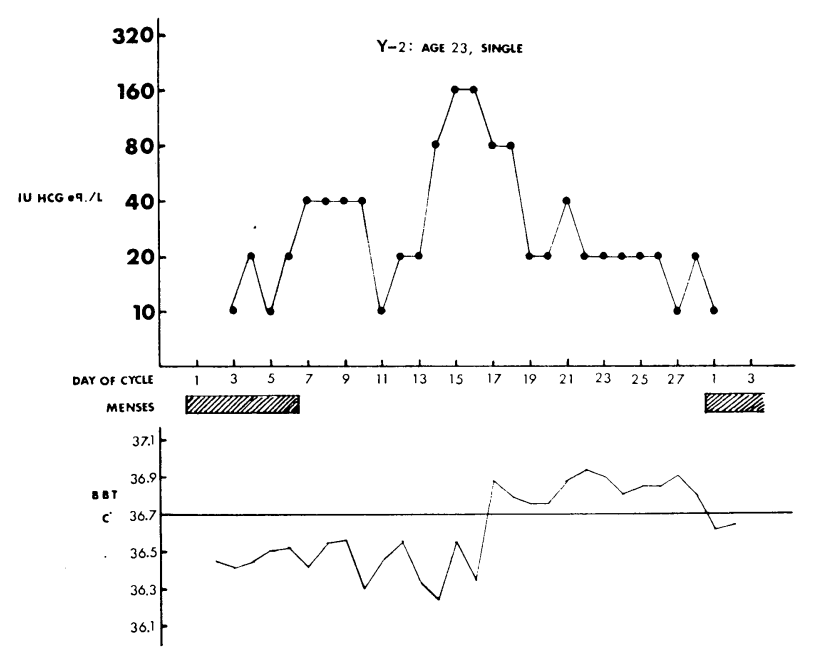

第 43 巻 第 1 号 
そ 160IU HCG eq./L のピークを 示した。

症例 S-1（27才，既婚，未経妊， Fig. 10) では，月経周期の第15，16 日（次回月経前15，14日目）に 160 IU IHGG eq./L のピークを示した.

症例 M-2（34才，既婚，3回経 産, Fig. 11）では，早朝尿について LH-Immunoassay を行ない，同時 に48時間尿より $\mathrm{G}$ 抽出を行つて， LH，FSH-Bioassay を行つたが，月 経周期の第18〜20日（次回月経前 15 $\sim 13$ 日目）に，LH-Immunoassay で 40〜80 IU HCG eq./L のピー クを示した. LH-Bioassay は，LHImmunoassay のピークに応じて高 值を示したが，FSH-Bioassay 值は むしろその時期には低值を示した。

症例 K-1（24才，未婚，Fig. 12） は，月経周期の第14日（次回月経前 14日目）に 80IU HCG eq./L., 症 例 T（23才，未婚, Fig. 13）は，月 経周期の第14日目（次回月経前15日 目) に 80IU HCG eq./L, 症例 L （25才，既婚，未経妊，Fig. 14）は 月経周期の第20日目（次回月経前13 日目）に 160IU HCG eq./L のピ 一クをそれぞれ示した。

これらの症例において，尿中 $\mathrm{LH}$ の排泄量がピークを示した時期は， いずれも BBT の変化の他に次回月 経前15〜13日の間にあるととから推 して排卵期と考えられる。

ii) LH-Immunoassay と LH., FSH-Bioassay の関係

前記の実験対象婦人の K.M.S につき，卵胞期に 1 回，排卵期には連続数回，分泌期に 1 回48時間尿を採 取して，LH-Immunoassay，LH-,FSH-Bioassay を行ない，それぞれの相互関係を検討した。その成績は図 15〜17の如くである.

症例 K-2(Fig. 15), M-3(Fig. 16) において, 黒い丸印で示される LH-Immunoassay 值は, 白いバーで示 されている LH-Bioassay 值と平行して増減しているが，LH-Immunoassay 值と黒いバーで示される FSHBioassay 值との間には，そのような関係は認められなかつた。

症例 S-2(Fig. 17) は，妊娠に移行した 1 例であるが，やはり前 2 症例と同様の傾向がみとめられた.

以上 3 例の成績をまとめたものが Tab. 3 である。

また，乙れらの成績について，X軸に対数目盛で LH-Immunoassay を，Y軸に LH-或はFSH-Bioassay a menstrual cycle

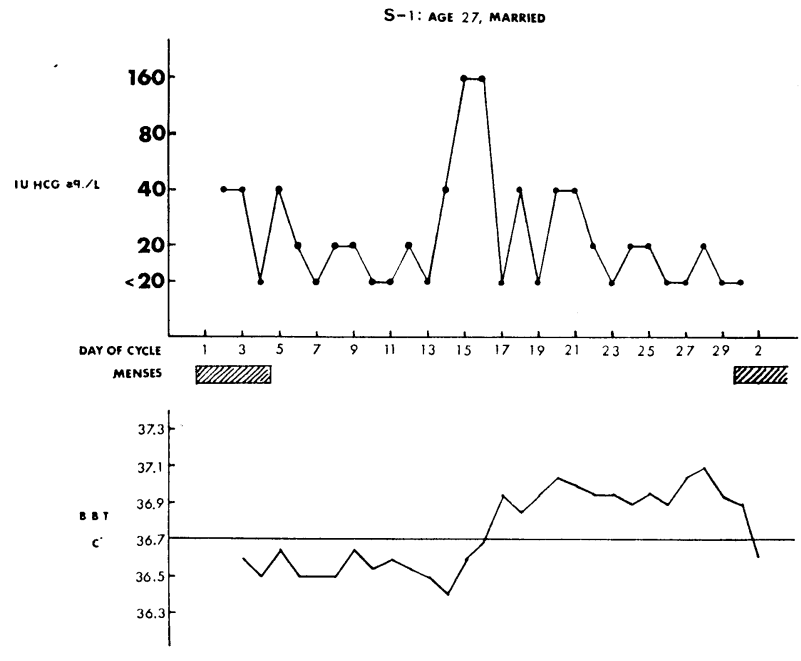

Fig. 11. LH-Immunoassay and LH-, FSH-Bioassay of the urine during a menstrual cycle

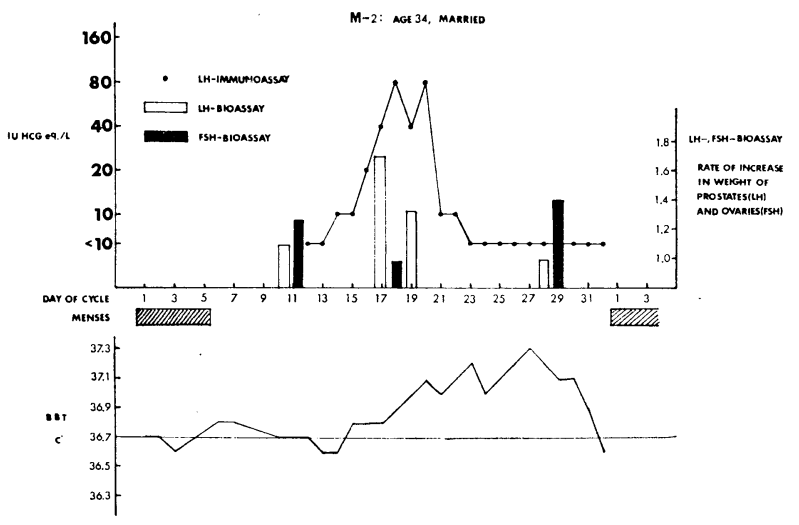


Fig. 12. LH-Immunoassay of the urine during a menstrual cycle
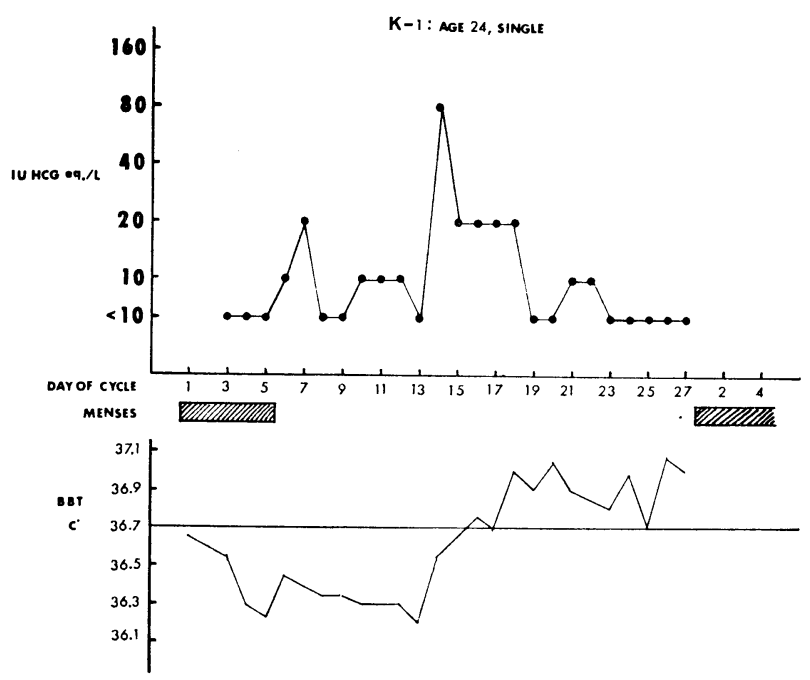

Fig. 13. LH-Immunoalssay of the urine during a menstrual cyce

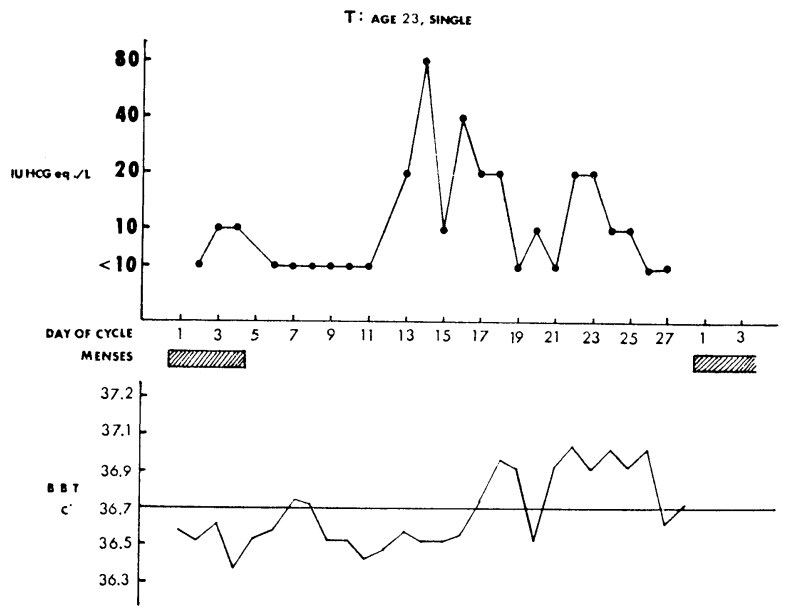

をとると，Fig. 18 のように，LH、 Immunoassay 值が増加するにした がつて, LH-Bioassay 值も次第に 増加しているととが明らかである が， Fig. 19 のようにLH-Immunoassay 值と FSH-Bioassay 值につい てはそのような一定の関係は認めら れなかつた。

\section{IV 総括ならびに考按}

LH の免疫学的測定には, Immunoassay の常識として LH の Antigen-antibody system を用いる のが理想的ではあるが，精製された 純度の高い LH の必要量を入手す るととは，実際には至難である。 Wide および Gemzell ら ${ }^{9)}$ (1961) が HGG と LH の間には crossreaction が成立し，それに基づいて LH-Immunoassay が可能であると 報告して以来，ての方法がにわかに 注目を集めるようになつた。 そして 実際に尿中 LH の測定を，てのよ うな方法で試みた報告も見られるよ うになつてきた 23) 28)，しかし，乙 のような免疫学的な LH 测定法が 果して真に LH を測定しているか そついては未だ明らかでない，その 理由として，HCG，LH はともに 未だ純粋には抽出されていないの で，乙れらのホルモンの抗原性につ いても不明の点が多く，しかも LH の Immunoassoy $と$, 生物学的活 性との関係についても諸家の報告は

必ずしも一致を見ていないてとが挙げられる。また， LH は HCG に比して尿中への排泄が微量であると 云う不利な条件下におかれているが，てのような条件下での LH 測定法についても充分な検討が行われね ばならない，以上のように，LH-Immunoassay には究明を要するに幾多の問題点を含んでいるので，未だ 一般に臨床検査として用いられる段階にまで到達していないものと考えられる。

そこで著者は，HCG とLHの抗原性について基礎的に検討を行ない，さらに尿中 LH の Immunoassay の測定条件について検討を行つた後，さらにその臨床応用を試み，かつ免疫学的活性と生物学的活性との相 関関係の有無についても検討した。

\section{1. 抗 HCG 血清について}

HCG 製剤の中には，その製品の純度に応じて数種類の夾雑蛋白質が混在しているととは，既に多数の研 第 43 巻 第 1 号 
Fig. 14. LH-Immunoassay of the urine during a menstrual cycle

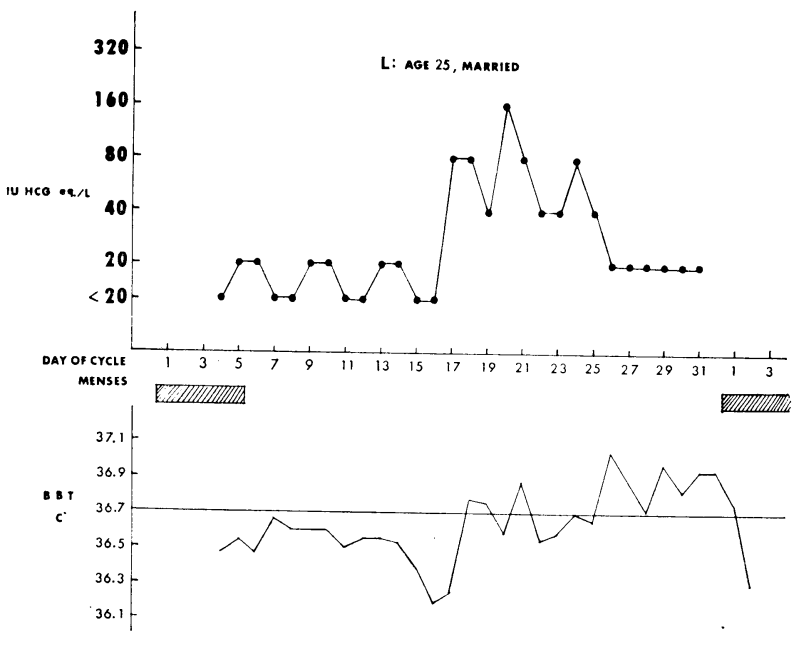

Fig. 15. LH-Immunoassay and LH-, FSH-Bioassay of the urine during a menstrual cycle

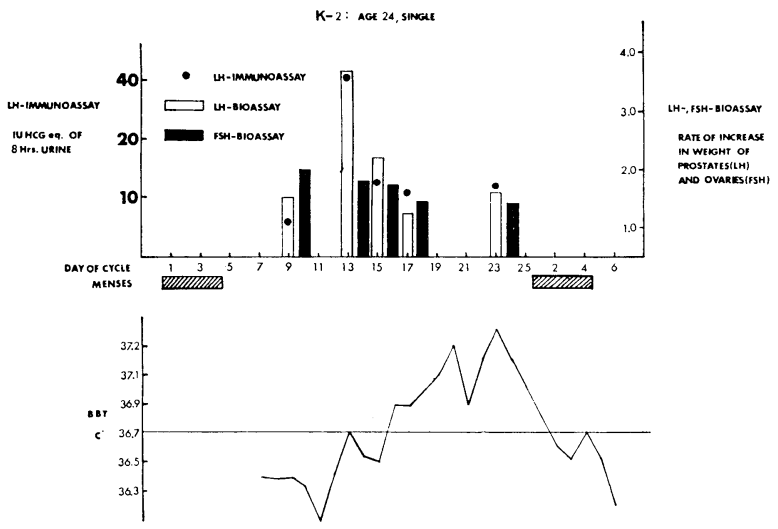

Fig. 16. LH-Immunoassay and LH-, FSH-Bioassay of the urine during a menstrual cycle

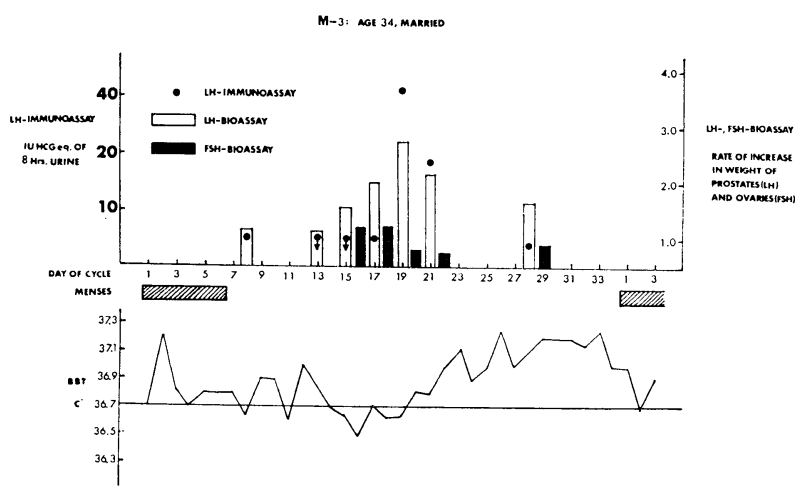

究者によつて報告されている、 ${ }^{5) \sim 7) ~}$ 29) 31)

著者が作製した抗 HCG 家鬼血 清においても尿蛋白，ヒト血清と共 通する数種類の夾雑蛋白に対する抗 体の存在することを免疫電気泳動法 によつて確認し得た。しかし，乙れ らの夾雑蛋白に対する抗体も, 吸収 操作によつて完全に除去することが できた。

2, LH と HCG の共通抗原性に ついて

Wide およびGemzell ら ${ }^{9}$ (1961)， Wide ${ }^{23)}$ (1962), Butt, Crooke, および Cunningham $ら^{32)}(1961)$ は, HAIR を用いて，又 Goss および Taymor $ら^{29) 33)}$ (1962.3) は, Latex-HCG Agglutination inhibition によつ $\tau$, HCG と LH の cross-reaction の存在することを報告している。ま た，Taymor および Goss ら ${ }^{29)}(1963)$ Shahani および Rao ら ${ }^{30}$ ) (1964), Goss および Lewis $~^{34}$ ) (1964) は, ゲル内沈降反応，免疫電気泳動法に よつて LH と HCG の問に crossreaction の存在することを報告して いる.

その他， HCG 或は LH が各々 抗 LH, 抗 HCG 血清により，そ の生物活性が 中和されるとの報告 は, Butt, Crooke および Cunningham $ら^{32)}$ (1961)，Mougdal および Li ら ${ }^{35)}$ （1961）その他多くの学者によつて なされている23229)33134).

著者は，精製純度の高い LH 製 剂を入手できなかつたので，LH お よび FSH を含む HMG 製剤を用 いて実験を行つた。その結果， HMG 中には, 吸収抗 HCG 血清 に対して HAIR，ゲル内沈降反応お よび免度電気泳動法において HCG と全く同じ反応を示す物質の存在す るととが明らかとなつた。しかも抗 
Fig. 17. LH-Immunoassay and LH-, FSH-bioassay of the urine during a menstrual cycle

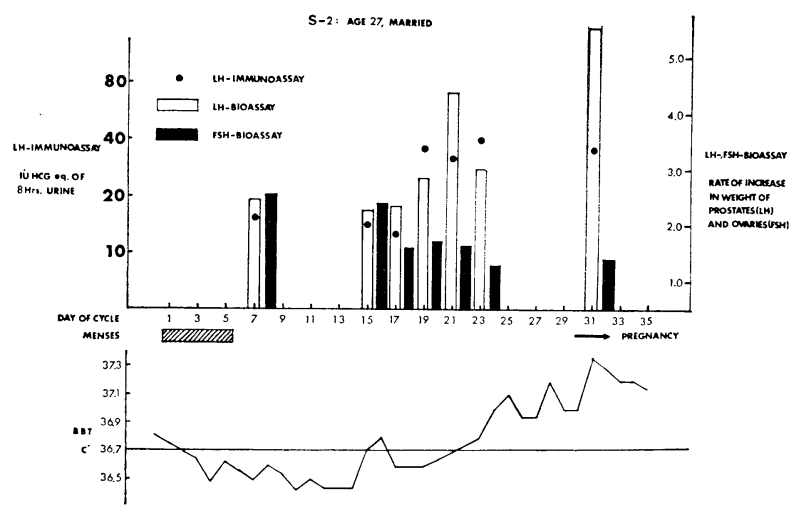

HCG 血清が HMG の生物学的活 性のうちの LH 作用を完全に中和 したが，FSH 作用には有意の影響 を与えなかつたととから，HCG と 同じ免疫学的反応を示す物質が LH であることが推定された。

Taymor および Goss ら $(1964,5)$ ${ }^{34) 36)}$ は, HCG と LH は, 抗HCG 血清に対して spur を以つて一本に つながると報告しているが，著者の

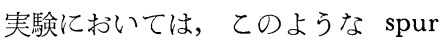
は出現しなかつた。これは， spur formation に関与する component

Table 3. Relationship between LH-immunoassay and LH-, FSH-bioassay

\begin{tabular}{|c|c|c|c|c|c|}
\hline \multirow{2}{*}{$\begin{array}{l}\begin{array}{c}\text { Case and } \\
\text { day of cycle }\end{array} \\
\mathrm{K}-2: 9,10\end{array}$} & \multicolumn{2}{|c|}{$\begin{array}{l}\text { FSH-Bioassay } \\
\text { Rate of increase } \\
\text { in weight of ovaries } \\
(\mathrm{M} \pm \mathrm{SE}) \\
\quad \text { No. of rats }\end{array}$} & \multicolumn{2}{|c|}{$\begin{array}{l}\text { LH-Bioassay } \\
\text { Rate of increase in } \\
\text { weight of ventral } \\
\text { prostates }(\mathrm{M} \pm \mathrm{SE}) \\
\quad \text { No. of rats }\end{array}$} & \multirow{2}{*}{\begin{tabular}{|l} 
LH-Immunoassay \\
IU HCG equivalent \\
5.6
\end{tabular}} \\
\hline & $2.0 \pm 0.10$ & 2 & $1.5 \pm 0.07$ & 4 & \\
\hline $\mathrm{K}-2: 13,14$ & $1.8 \pm 0.22$ & 2 & $3.6 \pm 0.26$ & 4 & 46.6 \\
\hline $\mathrm{K}-2: 15,16$ & $1.7 \pm 0.57$ & 2 & $2.2 \pm 0.17$ & 4 & 13.3 \\
\hline $\mathrm{K}-2: 17,18$ & $1.5 \pm 0.36$ & 2 & $1.3 \pm 0.13$ & 4 & 12.9 \\
\hline $\mathrm{K}-2: 23,24$ & $1.5 \pm 0.64$ & 2 & $1.6 \pm 0.11$ & 4 & 12.8 \\
\hline M-3 : 8,9 & - & & $1.2 \pm 0.29$ & 3 & 5.5 \\
\hline$M-3: 13,14$ & - & & $1.1 \pm 0.23$ & 4 & $5.5>$ \\
\hline$M-3: 15,16$ & $1.2 \pm 0.28$ & 2 & $1.6 \pm 0.18$ & 3 & $4.2>$ \\
\hline$M-3: 17,18$ & $1.2 \pm 0.42$ & 2 & $2.0 \pm 0.59$ & 4 & 3.5 \\
\hline$M-3: 19,20$ & $0.8 \pm 0.00$ & 2 & $2.8 \pm 0.41$ & 4 & 42.0 \\
\hline M-3: 21,22 & $0.8 \pm 0.10$ & 2 & $2.3 \pm 0.25$ & 4 & 18.7 \\
\hline$M-3: 28,29$ & $0.9 \pm 0.14$ & 2 & $1.7 \pm 0.16$ & 4 & 3.8 \\
\hline $\mathrm{S}-2: 7,8$ & $2.6 \pm 0.64$ & 2 & $2.6 \pm 0.38$ & 4 & 15.3 \\
\hline $\mathrm{S}-2: 15,16$ & $2.5 \pm 1.35$ & 2 & $2.4 \pm 0.38$ & 4 & 14.3 \\
\hline $\mathrm{S}-2: 17,18$ & $1.6 \pm 0.42$ & 2 & $2.4 \pm 0.49$ & 4 & 12.3 \\
\hline $\mathrm{S}-2: 19,20$ & $1.7 \pm 0.50$ & 2 & $3.0 \pm 0.22$ & 4 & 38.7 \\
\hline $\mathrm{S}-2: 21,22$ & $1.7 \pm 0.10$ & 2 & $4.5 \pm 0.66$ & 4 & 30.7 \\
\hline $\mathrm{S}-2: 23,24$ & $1.3 \pm 0.00$ & 2 & $3.2 \pm 0.22$ & 4 & 40.0 \\
\hline $\mathrm{S}-2: 31,32$ & $1.4 \pm 0.22$ & 2 & $5.7 \pm 0.90$ & 4 & 36.3 \\
\hline
\end{tabular}

が，著者の用いた抗原中に少なかつたか，或はあつても免疫のさい家鬼における抗体産生がほとんどなかつ たためと考朰れる。

また，Hamashige および Arquilla ら ${ }^{31}$ （1964）は，HCG の抗原性に関して，HAR，沈降反応に関与する 抗原一抗体と，生物学的活性に関与する抗原一抗体は別個のものであると主張しているが，ての点に関して は，今日未だ HCG，LH 抗原が純粋に抽出できない現況であるので今後の研究に待たねばならない. 
Fig. 18. Relationship between LH-Immunoassay and LH-bioassay

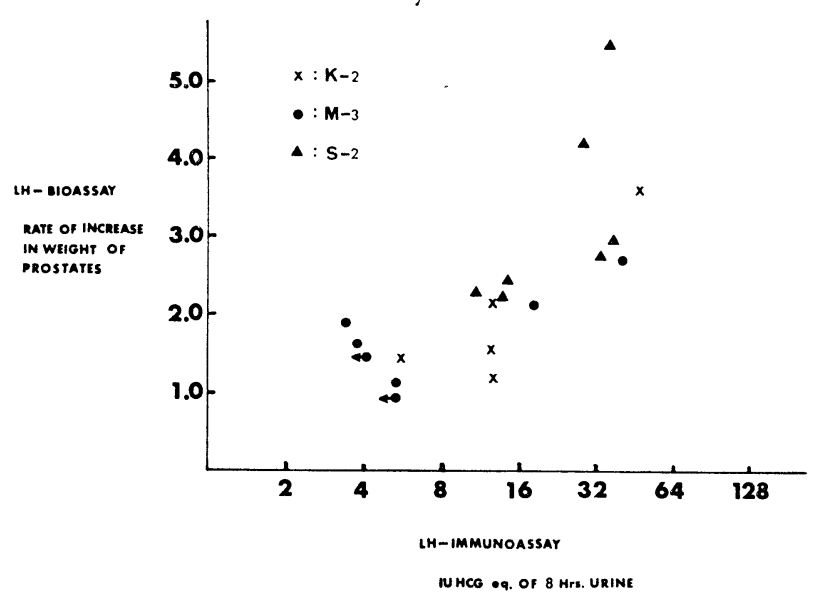

Fig. 19. Relationship between LH-immunoassay and FSH-bioassay

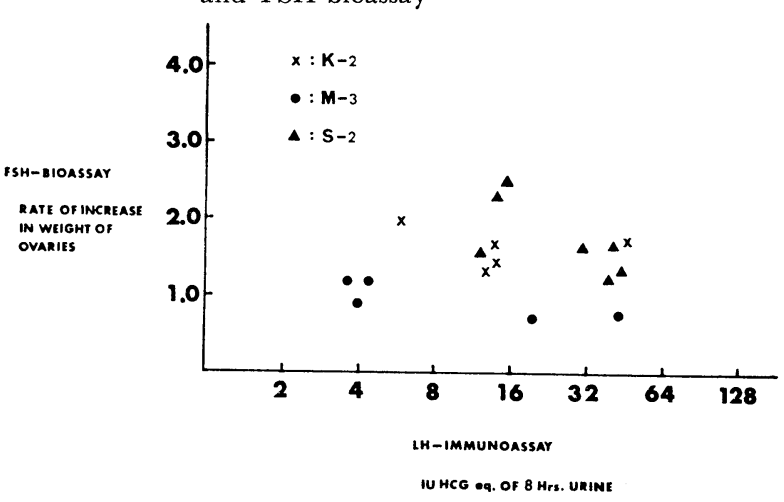

3. 尿中 LH-Immunoassay の実施 条件について

今日まで報告されている尿中LHImmunoassay は, 既存の HCGImmunoassay をそのまま応用した 測定法で実施されているが，HCG に比して生理的には極めて微量の尿 中 LH を免疫学的に測定するには 先ず測定法自体を充分に検討しなけ ればならない，特に尿中 LH-Immunoassay では，被検尿に濃縮操作 を加えるため，それだけ夾雑蛋白が 反応に関与する可能性が増大するの で，著者は夾雑蛋白に対する抗体を 完全に除去した吸収抗 HCG 血清 を用いた。 また, 従来の LH-Immunoassay では, 阻止感度決定に際 して, 既知単位の HCG について 生食水，または PBS の medium 中で決定しているが，実際の反応は $1 \sim 20$ 倍に濃縮された尿成分中で行 われる。乙のような尿成分の濃度 が，凝集阻止反応におよぼす影響を 検討してみると, 果して生食水又は PBS の medium 中の場合よりも, $1 \sim 20$ 倍の 濃度の尿成分中では, 1/4の HCG 濃度で凝集阻止が生ず ることを確認した。 したがつて，著 者は 2 倍に濃縮した小児尿中で凝集

阻止感度を決定し，また被検体の倍数稀釈を行い，正しい測定值を得るように努めた。

\section{4. 臨床成績について}

これまで Bioassay によつて，月経周期における尿中 LH の排泄は，排卵期に一致してそのピークが出 現することが知られている ${ }^{17) ~ 20) . ~}$

Immunoassay によつても同様に排卵期に尿中 LH がピークを示すととは Wide および Gemzell ら ${ }^{26)}$

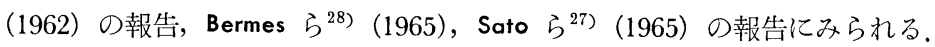

著者も, 吸収抗 HCG 血清が LH と免疫学的反応を起すととを基礎的に確認した後，乙の吸収抗 HCG 血清を用いて測定条件を予め検討した上で，尿中 LH-Immunoassay を試みた。 7 症例において，それぞれ 排卵期に一致して 80〜320 IU HCG eq./L のピークの出現するととを認めた。この測定值は，Wide およ び Gemzell ら ${ }^{26)}$ (1962)，Sato ら ${ }^{28)}$ (1965) の報告に比らべて全般的にやや低值を示しているが，乙れは 標準品として用いた HCG 製凨が異なること以外に，著者は吸収抗 HCG 血清を使用したとと，および阻 止感度決定，検体の稀釈に濃縮小児尿を使用したととなどが関係しているものと考えられる。

\section{5. 免疫学的測定值亡生物学的活性について}

LH-Immunoassay が Bioassay にとつて代つて臨床応用されるためには，両者が少くとも平行関係にあ 
るてとが当然必要となつて来る.

尿中 LH の Immunoassay 值と Bioassay 值の関係について, Wide および Gemzell ら ${ }^{9}$ (1961), Wide $(1962)^{23}$ は， 非妊婦尿濃縮物や HMG 製剂に関して両者の一致をみているが，Goss および Taymor ら ${ }^{33)}$ （1962）は，HMG 製剂についての比較実験で Bioassay 值/Immunoassay 值の比率が $2 〜 3$ 亿をると報 告し，Butt, Crooke および Cunningham ら ${ }^{25)}$ (1964) は，乙れとは反対に若年婦人の尿については，Bioassay 值に比して Immunoassay 值が相当高いてとがあるとのべている. 又, Hipkin ${ }^{24}$ (1965) も種々の内分泌疾 患を有する患者尿について調べたとてろ免疫学的活性はあつても生物学的活性の検出ができないものが多く あつたとのべている。

て以上のように，尿中 LH の Bioassay と Immunoassay の関係は，報告者によつて，必ずしも一致を みいないととに現今多大の疑問が集中されている。

しかし著者が行つた実験では, 標準となる純度の高いヒト LH がなかつたため, 尿中 LH の免疫学的活 性と生物学的活性を LH 量として直接比較できなかつたが，月経周期中の尿中 LH の Immunoassay 值 の消長は, Bioassay 值の動摇とよく一致し, 両者は略平行関係にあることを知つた，てのととは，Immunoassay により，尿中 LH の絶対量は知り得ないとしても，排泄量の増減を比較測定できるので，てれまで の Bioassay に代つて臨床的にも応用できるものと考えられる.

\section{V. 結 語}

HCG Antigen-antibody system を用いた HAIR による尿中 LH-Immunoassay そつき，基礎的ならび に臨床的検討を行ない，次の結果を得た。

1. HCG-P 中には, HCG 以外の血清蛋白, 尿蛋白成分が混在し, 抗 HCG 家鬼血清の作製に際してて れらの夾雑蛋白に対する抗体も産生されることを知つたので，先ず四収操作によりとれらの抗体を除くこと により，HCG とのみ反応する吸収抗 HCG 血清を作製した。

2. 吸収抗 HCG 血清に対して, HAIR，ゲル内沈降反応および允疫電気泳動法において，HCG と共通 の抗原性を示す物質が HMG-P 中にみられ，しかも HMG-P の LH 活性が抗 HCG 血清により完全に中 和されるととより，ての物質は LH であると推定される.

3. 吸収抗 HCG 血清および HCG 感作羊血球を用いた凝集阻止反応では，その阻止感度は 1 倍〜20倍 の範囲の濃度に濃縮された尿成分中では変化しないが，PBS 或は生食水中の場合と比較ずれば，1/4のHCG 濃度で凝集阻止が生じた。したがつて，濃縮被検尿について免疫学的に測定するには，同様に濃縮した小品 尿溶液を用いて稀釈，測定することが望ましい。

4. 7 例の正常月経周期婦人の早朝尿中 LH の Immunoassay を試みた結果, 月経周期の第14〜20日に 80〜320IU HCG eq/L のピークの出現するてとを認めた。 ての時期は, いずれも次回月経より逆算して, 15〜13日目に相当し，しかも基礎体温と併世考帛て，いわゆる排卵期に相当する時期である。

5. 3 例の正常月経周期婦人の?.月経周期の各時期の48時間尿につき, LH-Immunoassay および LH-, FSH-Bioassay を行つた結果, LH-Immunoassay 值の增減は, LH-Bioassay 值の増减と略平行したが, FSH-Bioassay 值とは一定の関係をみとめなかつた。

以上のととより, てのような LH の免疫学的測定法は, LH の尿中排泄量の増減を知る方法として臨床 的に意義あるものと考学られる.

稿を終るに当り, 御兓篬なる御指導御校閲を睗つた恩師足高教授に深甚の謝意を表します. 又本研究の実 施に当り直接御指導を頂いた徳大産婦人科礶島助教授书よび終始御教示御䩒遥を頂いた倉智助教授, 第二病 理学教室松本講師に感謝の意をささげます。

な抢。精製 HCG を提供された帝国価器製薬 KK 松島博士, Primogonyl を提供された日独薬品 K.K., Pergonal-500TM を提供された東洋醇造 K.K. およびラット下垂体剔出術に御協力を賜わつたシオノギ製 薬 $\mathrm{KK}$, 三宅研究室, 田中博士，小林博士，系賀氏に心より感謝いたします. 
1) WIDE, L., and GEMZELL, C.A. : Acta Endocrinol., 35 : 261, (1960)

2) BRODY, S. and GARLSTRÖM, G. : Lancet, II : 99, (1950) $\quad$ 3) MGKEAN, G.M. : Am. J. Obst. \& Gynec., 80 : 596, (1960) 4) ROBBINS, J.L., HILL, G.A., GARLE, B.N., CARLQUIST, J.H., and MARGUS, S. : Proc. Soc. Exper. Biol. \& Med., 109:321, (1962) 5) 足高善雄, 谷沢修: 産婦人 科治療，7 373，(1963)。 6 6) 谷沢修，磯島晋三：日本内分泌誌，39：08(1964) 7) 谷沢修：日産婦誌，17：145，((1965)。 $\quad$ 8) 磯島晋三，他：産婦の世界，18：520，(1966). 9) WIDE, L., ROOS, P., and GEMZELL, C. : Acta Endocrinol. : 37, 445, (1961) 10) GOSS, D.A. : J. Glin. Endocrinol., $24: 408,(1964) \quad 11)$ STAVITSKY, A.B. : J. Immunol., $72: 360$, (1954) 12) GREEP, R.O., VAN DYKE, H.B. and CHOW, B.F. : Proc. Soc. Exper. Biol. \& Med., 46 : 644, (1941)

13) 三宅有：日本内分泌誌，37：576, (1961).

14) 田中明 :

塩野義年報 $5: 678,(1955)$.

15) STEELMAN, S.L. and POHLEY, F.M. : Endocrinology, 53 :604, (1953). 16) 足高善雄, 磯島晋三 : 産之婦, $33: 33$, (1966).

17) MCARTHUR, J.W., WORGESTER, J., and INGERSOLL, F.M. : J. Glin. Endocrinol., $18: 1186$, (1958) 18) FUKUSHIMA, M., STEVENS, V.C., GANTT, G.L., and VORYS, N. : J. Clin. Endocrinol., 24 : 205 , (1964) 19) ROSEMBERG, E., and KELLER, P.J. : J. Glin. Endocrinol., 25 : 1262, (1965). 20）倉智敬一：第17回日産婦総会宿題報告要旨, p.229（1965）。 21）BRADBURY, J.T., BROWN, E.S. and BROWN, W.E. : Proc. Soc. Exper. Biol. \& Med., 71 : 228, (1947) 22) 松島早苗, 出口 雅之：ホと臨, $8: 749,(1960)$.

23) WIDE, L. : Acta Endocrinol., Suppl., 70, (1962) 24) HIPKIN, L.J. : Acta Endocrinol., $50: 224$, (1965) 25) BUTT, W.R., GROOKE, A.G., CUNNINGHAM, F.J. and INGRASSIA, F. : Proc. Roy. Soc. Med., 57 : 851, (I964) 26) WIDE, L., and GEMZELL, C.A. : Acta Endocrinol., 39 : 539, (1962)

27) SATO, T., GREENBLATT, R.B., and MAHESH, V.B. : Fertil. \& Steril., $16: 223$, (1965) 28) BERMES, E.W. Jr., HEFFERMAN, B.T. and ISAACS, J.H. : Obst. \& Gynec., 25 : 792, (1965) 29) TAYMOR, M.L., GOSS, D.A. et BUYTENDORP, A. : Fertil. \& Steril., 14 : 603, (1963) SHAHANI, S.K., and RAO, S.S. : Acta Endocrinol., 46 : 317, (1964)

31) HAMASHIGE, S., and ARQUILLA, E.R. : J. Clin. Investigation, $43: 1163$, (1963)

32) BUTT, W.R., GROOKE, A.G., and CUNNINGHAM, F.J. : Proc. Roy. Soc. Med., 54 : 647, (1961) 33) GOSS, D.A., and TAYMOR, M.L. : Endocrinology, $71: 321$, (1962) 34) GOSS, D·A., and LEWIS, J. JR. : Endocrinology, $74: 83$, (1964) 35) MOUGDAL, N.R., and LI, C.H. : Nature, 191 : 192, (1961)

36) TAYMOR, M.L., SARAVIS, C., BATT, R. and GOSS, D.A. : Fertil. \& Steril., $16: 579$, (1965) 